\title{
Voracity, reaction to stings, and survival of domestic hens when feeding on the yellow scorpion (Tityus serrulatus)
}

\author{
Gabriel Pimenta Murayama ${ }^{1,2 *}$ (D), Guilherme Ferreira Pagoti, (D), José Paulo Leite Guadanucci ${ }^{3}$ (D), \\ Rodrigo Hirata Willemart ${ }^{1,2}$ \\ ${ }^{1}$ Institute of Biosciences, University of São Paulo (USP), São Paulo, SP, Brazil. \\ ${ }^{2}$ School of Arts, Sciences and Humanities (EACH), University of São Paulo (USP), São Paulo, SP, Brazil. \\ ${ }^{3}$ Institute of Biosciences, State University of São Paulo (UNESP), Rio Claro, SP, Brazil.
}

\section{Keywords:}

Biological control

Buthidae

Natural enemy

Predator-prey interactions

\begin{abstract}
Background: Scorpionism is a worldwide problem that has already made thousands of victims, and multi-disciplinary approaches for controlling their populations are to be more successful. Hens are often mentioned as tools for controlling scorpions; however, systematic/experimental behavioral studies are not available. Moreover, there is no systematic information on the effect of scorpion venoms on hens. Using the venomous yellow scorpion Tityus serrulatus, the present study aimed to clarify the following aspects: (1) voracity of hens, (2) how hens react when stung, (3) the effect of scorpion stings on hen behavior during attacks, and (4) hen survivorship after feeding on scorpions.

Methods: We attracted hens with corn powder, offered them scorpions and then recorded the hen-scorpion interaction. To test the effects of the sting we manually removed the scorpion's telson. Results: We found that some hens ate up to six scorpions within minutes. By means of an ethogram and drawings, we showed that they exhibited several aversive behaviors when capturing scorpions. Removal of the scorpion telson stopped the aversive reactions, which was not observed in the control group. Finally, hens did not exhibit atypical behaviors after 1, 7 and 30 days and were all alive after 30 days. Conclusion: This is the first empirical and video recorded study providing evidence that hens are clearly affected by scorpion venom but do not die. Therefore, they may have potential to be used in biological control of these arthropods.
\end{abstract}

\section{Background}

Scorpionism is a widespread problem around the world, especially in regions of Africa, India, Mexico, Australia and South America [1,2]. In Brazil, the species responsible for the majority of accidents and deaths is the yellow scorpion Tityus serrulatus $[3,4]$. This species is originally from the Southeast of the country, but its distribution has expanded $[5,6,7,8]$. These scorpions are currently found in many States $[9$,$] and even$ in other countries such as Argentina and Bolivia $[6,10,11]$. Furthermore, T. serrulatus can reproduce by parthenogenesis

\footnotetext{
* Correspondence: pimentamurayama@gmail.com 
[12] and fast for long periods [13], making it an even more complex pest to control. Unfortunately, very few studies have addressed scorpion control $[14,15,16]$.

There are many methods for controlling pests, such as using plant extracts [17], fungi, bacteria [18], pesticides [19] and biological control by animals [20]. In some cases, biological control is a good alternative because it can be a cheap and nontoxic method to the environment [21,22]. For a successful and efficient biological control, the voracity of the introduced predator is an essential trait to be considered [23], obviously considering prey abundance. For example, an egret can consume around 100-150 grams of fly larvae each day in waste dump's areas [24], and a single ladybird beetle can eat around 100 aphids in 24 hours $[25,26]$. The more abundant the prey, the more voracious the predators used in pest control must be.

Toxic and venomous prey have to be dealt with care by the predator since prey can either kill or negatively affect predators' behavior [27,28]. However, some predators are able to remove or avoid toxic body parts of prey $[29,30]$ and others are immune to the prey venom [31]. Thus, predators used to control prey must have one of such characteristics, ultimately surviving attacks.

In scorpions, the possibility of using predators to help controlling their population locally has never been systematically tested. There are many animals that feed on scorpions and Polis et al. [32] have provided an extraordinary compilation of scorpion predators. The list includes other arachnids [33,34], mantids, chilopods, frogs, lizards, bats, birds and others. Birds are predators of arthropods in general [35,36,37,38], including scorpions $[39,40]$.

As many birds, the hen Gallus gallus domesticus is an omnivore animal [41], easily found around the world and cheap to obtain and rear. It easily adapts to synanthropic environments where most accidents with yellow scorpions occur. If the requirements mentioned above are met, hens could have potential to at least help controlling local populations of yellow scorpions. It is a common but controversial saying that hens are good to control scorpions. Based on a single person interviewed and from eight scorpions offered to a single hen that fed on the scorpions, Dias et al. [42] concluded that hens are scorpion predators and doubtless excellent for controlling scorpion populations. Cruz et al. [43] reported that the mayor of Aparecida city (in São Paulo State, Brazil) distributed hens to the population as an attempt to control scorpion infestation, but the efficacy was never tested. The Brazilian Ministry of Health [44] reported that hens are not efficient in controlling scorpions, but do not cite studies. There is definitely a need for a more detailed study on the predatory interaction between hens and scorpions. Here we studied the interaction between the hen G. gallus domesticus and the yellow scorpion T. serrulatus aiming to understand: (1) voracity of hens, (2) how hens react when stung, (3) the effect of the sting on hen behavior during attacks, and (4) hen survivorship after feeding on scorpions.

\section{Methods}

\section{General procedures}

We collected adult scorpions in the city of Santa Gertrudes (State of São Paulo, Brazil) between January and April 2019. We maintained scorpions in terraria (45 length $\mathrm{x} 21$ width $\mathrm{x}$ 30 height $\mathrm{cm}$ ) with water ad libitum and fed them cockroaches (Periplaneta americana) every 15 days. We carried out all the experiments in a private farm with hens in the city of Paulínia (State of São Paulo, Brazil) in May 2019, except the one described in the section "Hen response while feeding on scorpion with and without telson". The hens (Gallus gallus domesticus; $\mathrm{n}=50$ ) were maintained in an isolated area of 266 meters $^{2}$. Hen response while feeding on scorpion with and without telson meters ${ }^{2}$ with low trees, shelter and substrate covered by soil, grass, tree trunks and pieces of wood. For experiment in the section "Hen response while feeding on scorpion with and without telson", we collected scorpions in the city of Botucatu (State of São Paulo, Brazil) in September 2020. We carried out this experiment in another private farm with hens in the city of Paulínia (State of São Paulo, Brazil) in October and November 2020. The hens used in this experiment were maintained as described above, but in this farm the hens had an area of 550 meters $^{2}$.

We used hens that were being fed daily with enriched bird food and corn kernels. Hens had never been seen interacting with scorpions before the experiment and had never been seen in the surroundings of the experimental areas. Before starting the experiments, we observed the hens for about 30 minutes. During this period, we observed the hens walking, approaching us, scratching themselves and eating normally. We observed henscorpion interactions between 1 and 4 PM for two consecutive days. We made the observations where the hens were being maintained to minimize stress due to translocation. Because the hens had been reared free and in group, we also did not individualize them in cages to avoid stress that could lead to unusual behaviors.

\section{Reaction to scorpion stings}

To describe the interactions between hens and scorpions, we attracted hens with corn powder. When at least one hen was approximately $2 \mathrm{~m}$ from us, we released, using tweezers, a live scorpion at a distance of approximately $30 \mathrm{~cm}$ from the hen's body. An average of 3.4 hens (minimum 1, maximum 10 hens) were close to us when the first hen captured the scorpion. We offered a total of 61 scorpions. We recorded (Sony Handycam HDR-XR55) all hen behaviors, from the moment we offered the scorpion until it was completely swallowed by one of the hens. We scored whether the hen was stung or not (see "Video analyses" section), hen reaction to scorpion stings (in behavioral categories) and the number of hens that fed on scorpions. 


\section{Video analyses}

By analyzing the videos, we verified which hens had been stung. Unfortunately, due to the quality and distance at which the records were made, we were unable to detect the sting penetrating in the hen integument. We inferred that hens were stung because: (1) the specific hen behaviors we have observed occurred right after the hen made contact with the scorpion or swallowed it and (2) hens in their regular activities before the experiments had never behaved these ways. Therefore, these behaviors were used as proxies of a scorpion sting throughout the study and this text. The possibility that some hens were stung but did not show any detectable reaction cannot be ruled out. We then analyzed the videos and built an ethogram of the predatory interaction.

\section{Hen survival after feeding on scorpions}

To investigate the venom's effect on hens, we monitored hens' behavior one, seven and 30 days after feeding on the scorpions. We scored whether the hens behaved as previously to the exposure to scorpions, presented atypical behaviors or died.

\section{Hen response while feeding on scorpions with and without telson}

To test if hen's behaviors were actually in response to the scorpion sting, we removed the telson by cutting the constriction between the telson and the metasoma with scissors. We then offered 26 scorpions without telson and 40 control scorpions (with telson) to the hens $10 \mathrm{~min}$ after the cut. Because of the limited number of hens, we used a repeated measures design in which the same hens were exposed to both treatments. Therefore, because we knew from previous observations (see "Reaction to scorpion stings") that hens would probably react aversively in the control group, here we first offered the treatment group to minimize possible effects of previous aversive reactions. The methods to attract, offer the scorpion and record the interaction between the hens and scorpions were the same as in "Reaction to scorpion stings". However, in this case the area used for observations had 25 meters $^{2}$. We divided the number of scorpions to which a hen had at least one aversive behavior by the number of scorpions it attacked. We compared only hens that captured prey in both treatments. We ran a Wilcoxon test comparing the treatment vs the control group. Because a single hen sometimes interacted with several scorpions, we also compared the number of scorpions that hens attempted to prey upon between the control and treatment groups to control for the probability of hens having aversive behaviors.

\section{Results}

\section{Description of scorpion capture}

In 41 out of 61 interactions we were able to identify which hen ingested the scorpion. In the remaining 20 interactions, we only witnessed hens holding dead scorpions but failed to register ingestion. It is, however, most likely that these scorpions were also ingested. When the scorpion is alive it tries to hold the hen with pedipalps, we then considered that the scorpion was dead when we saw the scorpion swing on hens' beak. While handling the scorpion, the most common behavior observed was to hold it within the beak and hit it against the substrate before ingesting. Hens consumed between 1 and $3(n=15), 6$ $(\mathrm{n}=2)$ and $7(\mathrm{n}=1)$ scorpions.

\section{Reaction to scorpion stings}

Hens were stung in 29 occasions out of 61 scorpions offered (nineteen interactions, some hens were stung more than once). Most hens $(\mathrm{n}=27)$ that were stung by scorpions immediately released them. In addition, they presented certain typical poststing behaviors, such as shaking their heads (Fig. 1A and 1B) and scratching their beaks and/or their faces with their feet (Fig. 1C, see other behaviors and descriptions in Table 1 and in the video of the Additional file 1). Most hens performed more than one of these behaviors when capturing a scorpion that stung. The other 42 did not exhibit any of these listed behaviors when attempting to capture the offered scorpion. None of these behaviors had been observed before the experiments.

\section{Hen survival after feeding on scorpions}

Among hens that displayed one of the above-mentioned aversive behaviors, hens were stung on average 1.7 times ( $\operatorname{std} \mathrm{dev}=0.9$, $\min =1 ; \max =4$ ) during the descriptive part of the study. All of these hens $(n=18)$ were alive, feeding and showing no atypical behavior one, seven and 30 days after feeding on scorpions. During the experiment below (with vs. without telson), a single hen was stung up to six times in 60 minutes and was still alive after the experiment with all the hens finished. We did not monitor it afterwards.

\section{Hen response while feeding on scorpions with and without telson}

Hens in the treatment group attacked 4 scorpions (median, $\min =1, \max =12)$ and those in the control group attacked 2.5 scorpions (median, $\min =1, \max =9)$ (Wilcoxon test; $\mathrm{W}=14$; $\mathrm{P}=0.426$ ). Hens showed aversive reactions in about half their interactions with scorpions with telson (median $=0.55 ; \mathrm{min}$ $=0 ; \max =1$ ) but none had aversive reactions with scorpions without telson (Wilcoxon test; $\mathrm{W}=36 ; \mathrm{P}=0.008$ ).

Being stung did not prevent some hens to keep attempting to capture scorpions. All six hens (during this experiment) that released the scorpion after being stung tried to recapture right after having dropped it. Being stung also did not prevent them from attacking scorpions: the most striking examples are three individuals that attacked 6, 9 and 11 scorpions after being stung in less than $40 \mathrm{~min}$. 

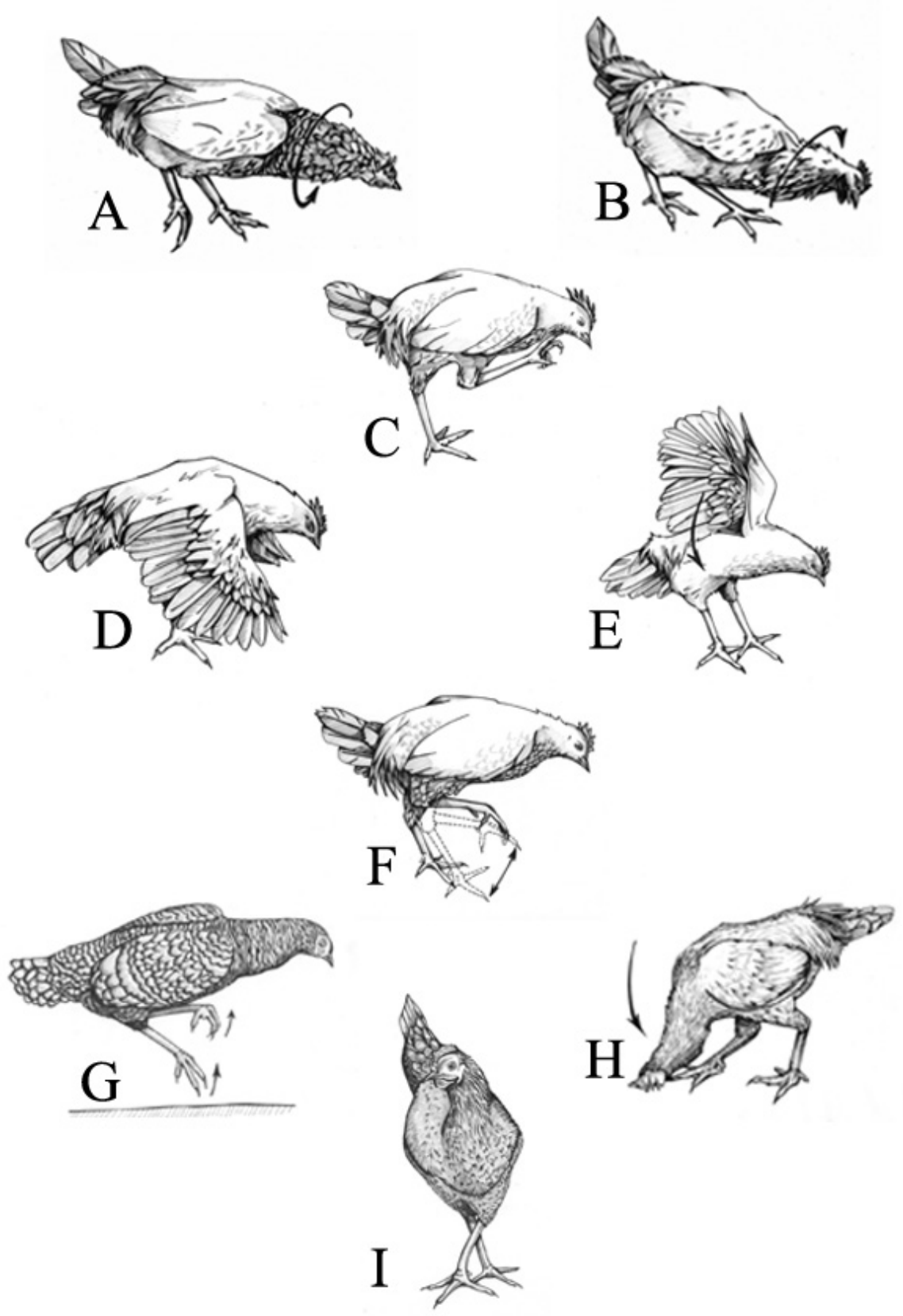

Figure 1. Representation of the aversive behaviors of the hen Gallus gallus domesticus when interacting with the yellow scorpion Tityus serrulatus. (A, B) shaking head; (C) scratch the beak/face with feet; (D, E) open wings; (F) stomp; (G, I) - jump; (H) - scratch the beak/face on substrate.

Table 1. Aversive behaviors of the domestic hen Gallus gallus domesticus after being bitten by the yellow scorpion Tityus serrulatus.

\begin{tabular}{|c|c|c|}
\hline Category & Description & $\mathbf{N}$ \\
\hline Shaking head & Move the head quickly and successively latero-laterally (Fig. 1, A and B) & 29 \\
\hline Scratch the beak/face with feet & Rub the beak and/or face with one foot at least once (Fig. $1 \mathrm{C}$ ) & 14 \\
\hline Stomp & $\begin{array}{l}\text { Raising and lowering successively one foot and then the other in repeated } \\
\text { movements (Fig. 1 F) }\end{array}$ & 2 \\
\hline Scratch the beak/face on substrate & Rub the beak laterally against the substrate (Fig. $1 \mathrm{H})$ & 2 \\
\hline
\end{tabular}




\section{Discussion}

We have shown that hens are voracious scorpion predators and that they may react aversively in different ways to scorpion defenses. Since hens have nociceptors (pain receptors) in the beak $[45,46]$, these aversive behaviors are probably due to the pain caused by the T. serrulatus sting. We have also provided experimental evidence that it is probably the sting that causes hens reactions and have shown that hens do not exhibit atypical behaviors after 1, 7 and 30 days and are all alive after 30 days.

One important criterium a predator has to meet to be a potential good species to control a pest is being voracious towards the specific prey. Hens clearly fit this criterium, having attacked up to 11 scorpions in less than $40 \mathrm{~min}$. Were the hens not grouped with other hens, they would probably eat larger quantities. Other evidences of voracity are that hens would quickly move towards the given scorpions and would often try to steal from their counterparts. According to the author's observations, hens clearly preferred scorpions over of powder corn.

A second criterium is to somehow not let stinging by the prey hamper the attack. Forty-two out of 61 scorpions did not cause any aversive reaction, suggesting they did not get to sting. This suggests hens are efficient scorpion predators. When pressed against the substrate or manipulated, scorpions defend themselves mainly by driving their pedipalps and metasoma towards the aggressor, pinching and stinging [47,48]. Contrary to what has been reported by Dehghani et al. [49] in interactions between Iranian species of scorpions and hens, the yellow scorpion often successfully stung the hens, which reacted in different ways (Table 1; Fig. 1A-1I). However, being stung did not prevent hens to continue the attack and chase other scorpions afterwards. As has been previously reported, reacting aversively when stung by scorpions does not mean aborting the attack ([50] example with lizards). All hens survived the attacks despite being stung several times in less than an hour. The venom of T. serrulatus is a cocktail that includes powerful neurotoxins [51,52]. Carcamo-Noriega et al. [53] found that a dose of 125 $\mu \mathrm{g} / \mathrm{kg}$ and the injection of $100 \mu \mathrm{L}$ of the scorpion Centruroides sculpturatus isolated venom were lethal to hens. The controlled quantity of venom used, the fact that Carcamo-Noriega et al. [53] used isolated toxins and the different scorpion species might explain the distinct results. Scorpions can control the amount of venom used [54] and because in our experiment it was a lifeor-death situation, it is reasonable to assume that scorpions did not use dry stings [54].

Finally, a third criterium is that predators have to survive most of the attacks towards venomous prey. Since all the hens were alive and sound 30 days after the experiment, these birds meet the requirement of not getting killed by the yellow scorpion. Hens are not the only predator that seems to be immune to stings of the yellow scorpion. Jared et al. [55] have shown that the toad Rhinella icterica also survive after feeding on T. serrulatus, with the advantage of being a nocturnal animal and therefore with a great overlap between the activity periods of toads and scorpions, but the disadvantage of being harder to obtain and maintain in synantropic environments.

There are several requirements for a predator to be an adequate species to control specific prey. We have shown that the most basic ones have been met by Gallus gallus domesticus, namely being a voracious predator of the yellow scorpion and being immune to the venom even if hens often react aversively to the sting. It is common sense that hens are good for biological control of scorpions. However, hens are said to be diurnal and yellow scorpions are mainly nocturnal [56]. Interestingly, hens may also have nocturnal activity. We have monitored 17 individuals between $18 \mathrm{~h}-6 \mathrm{~h}$ for two days and have data showing that, at night, they have different behaviors such as cleaning, scratching and walking. While walking, they sometimes wake up other hens. We also have data, that will also be published elsewhere, showing that hens will also feed on scorpions at night (Murayama, Pagoti and Willemart, unpublished data). Therefore, we have shown that at least the most fundamental requirements for a species to be used to control a specific prey have been met by hens.

\section{Conclusion}

We have shown that hens meet important criteria if they are to be used to control local populations of scorpions. They may consume several individuals and although the sting causes hens to react aversively, they all survive and behave normally afterwards.

\section{Acknowledgments}

We thank Luis Fernando García Hernández for the invitation to submit a contribution to the special issue "Arthropods: venoms and biology”. Silvia Helena Augusto, former Chief of City Health Units of Santa Gertrudes was immensely helpful with logistics for obtaining scorpions. We are grateful to Meire Murayama and to Gilmar Campos for kindly providing lodge and hens. We are also grateful to Mr. Miguel for kindly letting us use his hens.

\section{Availability of data and materials}

The datasets generated during and/or analyzed during the current study are available from the corresponding author on reasonable request.

\section{Funding}

Funding was provided by the Brazilian Coordination for the Improvement of Higher Education Personnel (CAPES) and International Society of Arachnology (ISA), Student Research Fund for financial support to GPM.

\section{Competing interests}

The authors declare that they have no competing interests. 


\section{Authors' contributions}

GPM, GFP and RHW designed the manuscript. JPLG provided the scorpions. GPM and GFP collected the data. GPM and RHW analyzed the data. GPM and RHW wrote the manuscript. GFP, RHW and JPLG reviewed the manuscript.

\section{Ethics approval}

The present study was approved (n. 368/2020) by the Ethics Committee on Animal Use of the Institute of Biosciences of the University of São Paulo (USP).

\section{Consent for publication}

Not applicable.

\section{Supplementary material}

The following online material is available for this article:

Additional file 1. Video showing aversive and non-aversive behaviors of hens.

\section{References}

1. Chippaux JP, Goyffon M. Epidemiology of scorpionism: A global appraisal. Acta Trop. 2008 Aug;107(2):71-9.

2. Santos MSV, Silva CGL, Silva Neto B, Grangeiro Junior CRP, Lopes VHG, Teixeira Junior AG, Bezerra DA, Luna JVCP, Cordeiro JB, Gonçalves Jr J, Lima MAP. Clinical and epidemiological aspects of scorpionism in the world: a systematic review. Wilderness Environ Med. 2016 Dec;27(4):504-18.

3. Pucca MB, Oliveira FN, Schwartz EF, Arantes EC, Lira-Da-Silva RM. Scorpionism and dangerous species of Brazil. Toxinology. 2014 Jan;1:1-24.

4. Bochner R, de Souza CMV. Divergences between the Brazilian national information systems for recording deaths from venomous animals. J Venom Anim Toxins incl Trop Dis. 2019 May;20:1-9. doi: 10.1590/1678-9199-JVATITD-1430-18.

5. Torres JB, Marques MCB, Martini RK, Borges CVA. An accident involving Tityus serrulatus and its epidemiological implications in Brazil. Rev Saúde Públ. 2002 Oct 1;36(5):631-3.

6. Rosa CM, Abegg AD, Borges LM, Bitencourt GSS, Di Mare RA. New record and occurrence map of Tityus serrulatus Lutz \& Mello, 1922 (Scorpiones, Buthidae) in the state of Rio Grande do Sul, southern Brazil. Check list. 2015 Jan 26;11(1):1556.

7. Lourenço WR. What do we know about some of the most conspicuous scorpion species of the genus Tityus? A historical approach. J Venom Anim Toxins incl Trop Dis. 2015;21(1):20. doi: 10.1186/s40409-015-0016-9.

8. Costa GG, Serejo LFM, Coelho JS, Cândido DM, Gadelha MAC, Pardal PPO. First report of scorpionism caused by Tityus serrulatus, described by Lutz and Mello, 1922 (Scorpiones, Buthidae), a species non-native to the state of Pará, Brazilian Amazon. Rev Soc Bras Med Trop. 2020;53:e20190285.

9. Lourenço WR. What do we know about some of the most conspicuous scorpion species of the genus Tityus? A historical approach. J Venom Anim Toxins incl Trop Dis. 2015 Jun 10;21:20. doi: 10.1186/s40409-015-0016-9.

10. Camargo FJ, Ricciardi AIA. Sobre la presencia de un escorpíón Tityus serrulatus Lutz e Mello (Scorpiones, Buthidae) en la ciudad de Corrientes. Universidad nacional del nordeste. Comun Cient Tecnol. 2000;1-3.

11. Lopez CA, Couto E, Gularte A. Escorpionismo y primeros registros de Tityus trivittatus y Tityus serrulatus en puerto iguazú, provincia de misiones. Rev Arg Salud Pub. 2019;10(40):51-4.

12. Matthiensen FA. Parthenogenesis in scorpion. Evolution. 1962 Jun;16:255-6.

13. Pimenta RJG, Brandão-Dias PFP, Leal HG, Carmo AO, Oliveira-Mendes, BBR, Chávez-Olórtegui C, Kalapothakis E. Selected to survive and kill: Tityus serrulatus, the Brazilian yellow scorpion. PloS One. 2019;14(4):e0214075.
14. Ramsey JM, Salgado L, Cruz-Celis A, Lopez R, Alvear AL, Espinosa L. Domestic scorpion control with pyrethroid insecticides in Mexico. Med Vet Entomol. 2002 Dec;16(4):356-63.

15. Albuquerque CMR, Barbosa MO, lannuzzi L. Tityus stigmurus (Thorell, 1876) (Scorpiones; Buthidae): response to chemical control and understanding of scorpionism among the population. Rev Soc Bras Med Trop. 2009 Mai-Jun 1;42(3):255-9.

16. Santos $A B$, Albuquerque CMR. Behavioural changes in Tityus stigmurus (Thorell, 1876) (Scorpiones: Buthidae) exposed to a pyrethroid insecticide. J. Ethol. 2020 Sep;38(3):301-10.

17. Siam A, Othman E. Field evaluation of botanicals extracts for suppressing the mango scale insect, Aulacaspis tubercularis (Newstead) (Hemiptera: Diaspididae). Egypt J Biol Pest Control. 2020 Mar02;30(1):1-5.

18. Nawaz A, Gogi MD, Naveed M, Arshad M, Sufyan M, Binyameen M, Islam SU, Waseem M, Ayyub MB, Arif MJ, Ali H. In vivo and in vitro assessment of Trichoderma species and Bacillus thuringiensis integration to mitigate insect pests of brinjal (Solanum melongena L.). Egypt J Biol Pest Control. 2020 May 18;30(1):1-7.

19. Jallow MFA, Awadh DG, Albaho MS, Devi VY, Thomas BM. Pesticide risk behaviors and factors influencing pesticide use among farmers in Kuwait. Sci. Total Environ. 2017 Jan 01;574:490-8.

20. Waterhouse DF, Sands DPA. Classical biological control of arthropods in Australia. Canberra (CBR): CSIRO Entomology (Canberra) and CSIRO Publishing (Melbourne). 2001.

21. Gurr GM, Wratten SD. Biological control: measures of success. 1st ed. Gurr G, Wratten S, editor. Springer Science and Business Media Dordrecht. 2000.

22. Simberloff D, Peter Stiling. How risky is biological control? Ecology (Durham). 1996 Oct 01;77(7):1965-74.

23. Ahmad SN, Masri MMM, Kamarudin N. Assessment on voracity and predation by predator, Sycanus dichotomus STAL. (Hemiptera:Reduviidae) to oil palm bagworm, Pteroma pendula. J. Oil Palm Res. 2020 Sep;32:480-7.

24. Seedikkoya K, Azeez PA, Shukkur EAA. Cattle Egret as a biocontrol agent. Zoos Print J. 2007 Sep 21;22(10):2864-6.

25. Cabral S, Soares AO, Garcia P. Predation by Coccinella undecimpunctata L. (Coleoptera: Coccinellidae) on Myzus persicae Sulzer (Homoptera: Aphididae): Effect of prey density. Biol. Control. 2009 Jul;50(1):25-9.

26. Cabral S, Soares A, Garcia P. Voracity of Coccinella undecimpunctata: effects of insecticides when foraging in a prey/plant system. J Pest Sci. 2011 Jul 21;84(3):373-9.

27. Covacevich J, Archer M. The distribution of the Cane Toad, Bufo marinus, in Australia and its effects on indigenous vertebrates. Mem Queensl Mus. 1975 Jan;17(2):305.

28. Smith JG, Phillips BL. Toxic tucker: the potential impact of cane toads on Australian reptiles. Pac Conserv Biol. 2006 Jan;12(1):40-9.

29. Barbaro $L, B a t t i s t i A$. Birds as predators of the pine processionary moth (Lepidoptera: Notodontidae). Biol Control. 2011 Feb;56(2):107-14.

30. Mebs D, Wunder C, Pogoda W, Toennes SW. Feeding on toxic prey. The praying mantis (Mantodea) as predator of poisonous butterfly and moth (Lepidoptera) caterpillars. Toxicon. 2017 Jun 1;131:16-9.

31. Hopp BH, Arvidson RS, Adams ME, Razak KA. Arizona bark scorpion venom resistance in the pallid bat, Antrozous pallidus. PLoS One. 2017 Aug 30;12(8):e0183215.

32. Polis GA, Sissom WD, McCormick SJ. Predators of scorpions: field data and a review. J Arid Environ. 1981 Dec;4(4):309-26.

33. Gunnarsson B. Bird predation and vegetation structure affecting spruceliving arthropods in a temperate forest. J Anim Ecol. 1996 May 1;65(3):38997.

34. Gunnarsson B. Bird predation on spiders: ecological mechanisms and evolutionary consequences. J Arachnol. 2007 Dec 1;35:509-29.

35. Ferger SW, Böhning-Gaese K, Wilcke W, Oelmann Y, Schleuning M. Distinct carbon sources indicate strong differentiation between tropical forest and farmland bird communities. Oecologia. 2013 Feb;171(2):473-86.

36. Maas B, Karp DS, Bumrungsri S, Darras K, Gonthier D, Huang NC, Lindell CA, Maine JJ, Mestre ML, Michel NL, Morrison EB, Perfecto I, Philpott SM, Sekercioglu CH, Silva RM, Taylor PJ, Tscharntke T, Van Bael SA, Whelan C], Willians-Guillén K. Bird and bat predation services in tropical forests and agroforestry landscapes. Biol Rev. 2016;91(4):1081-101. 
37. Nazaro MB, Blendinger PG. How important are arthropods in the diet of fruit-eating birds? Wilson J Ornithol. 2017 Sep 1;129(3):520-7.

38. Nyffeler M, Şekercioğlu ÇH, Whelan CJ. Insectivorous birds consume an estimated 400-500 million tons of prey annually. The Sci Nat. 2018 Jul 9;105:47.

39. Pande S, Pawashe A, Bastawade DB, Kulkarni PP. Scorpions and molluscs: Some new dietary records for Spotted Owlet Athene brama in India. Newsl Ornithol. 2004 Sep-Oct;1(5): 68-9.

40. Carevic FS, Carmona ER, Muñoz-Pedreros A. Seasonal diet of the burrowing owl Athene cunicularia Molina, 1782 (Strigidae) in a hyperarid ecosystem of the Atacama desert in northern Chile. J Arid Environ. 2013 Oct;97:237-41.

41. Tsukahara T, Ushida K. Effects of animal or plant protein diets on cecal fermentation in guinea pigs (Cavia porcellus), rats (Rattus norvegicus) and chicks (Gallus gallus domesticus). Comp Biochem Physiol A Mol Integr Physiol. 2000 Oct;127(2):139-46.

42. Dias E, Libiano S, Lisboa M. Lucta contra os escorpiões. Trabalho do instituto Oswaldo Cruz (filial) de Belo Horizonte. E, de Minas. p. 1-25. 1922.

43. Cruz EFS, Yasuda CRW, Jim J, Barraviera B. Programa de controle de surto de escorpião Tityus serrulatus, Lutz e Mello 1922, no município de Aparecida, SP (Scorpiones, Buthidae). Rev Soc Bras Med Trop. 1995 Abr-Jun;28(2):123-8.

44. Ministério da saúde. Manual de controle de escorpiões. 1st ed. Serie B. Textos básicos de saúde (Brasília). 2009.

45. Gentle MJ. Cutaneous sensory afferents recorded from the nervus intramandibularis of Gallus gallus var domesticus. J Comp Physiol A. 1989 Feb;164(6):763-74.

46. Gentle MJ. Pain in birds. Anim. Wel Anim. 1992;1(4):235-47.

47. Palka JT, Babu KS. Toward the physiological analysis of defensive responses of scorpions. Z Vgl Physiol. 1967;55:286-98.
48. Carlson BE, McGinley S, Rowe MP. Meek males and fighting females: sexually-dimorphic antipredator behavior and locomotor performance is explained by morphology in bark scorpions (Centruroides vittatus). PloS One. 2015 May 28;9(5):e97648.

49. Dehghani R, Valizade R, Mahmoodi S. A review of the scorpion predators and the introduction of Scarites subterraneus, as a new predatory of them in Iran. J Entomol Res. 2016;40(3):291-6.

50. O'Connell DJ, Formanowicz DR. Society for the study of amphibians and reptiles differential handling of dangerous and non-dangerous prey by naive and experienced Texas spotted whiptail lizards, Cnemidophorus gularis. J Herpetol. 1998 Mar 03;32(1):75-9.

51. Pucca MB, Cerni FA, Pinheiro Junior EL, Bordon KCF, Amorim FG, Cordeiro FA, Longhim HT, Cremonez CM, Oliveira GH, Arantes EC. Tityus serrulatus venom - A lethal cocktail. Toxicon. 2015 Dec 15;108:272-84.

52. Nencioni ALA, Beraldo Neto E, de Freitas LA, Dorce VAC. Effects of Brazilian scorpion venoms on the central nervous system. J Venom Anim Toxins incl Trop Dis. 2018 Jan 23;24:3. doi: 10.1186/s40409-018-0139-x.

53. Carcamo-Noriega EN, Olamendi-Portugal T, Restano-Cassulini R, Rowe A, Uribe-Romero SJ, Bercerril B, Possani LD. Intraspecific variation of Centruroides sculpturatus scorpion venom from two regions of Arizona. 2018 Jan 15;638:52-7.

54. Nisani Z, Honaker A, Jenne V, Loya F, Moon H. Evidence of airborne chemoreception in the scorpion Paruroctonus marksi (Scorpiones: Vaejovidae). J Arachnol. 2018 Apr 01;46(1):40-4.

55. Jared C, Alexandre C, Mailho-Fontana PL, Pimenta DC, Brodie Jr ED, Antoniazzi MM. Toads prey upon scorpions and are resistant to their venom: A biological and ecological approach to scorpionism. Toxicon. 2020 Apr;178:4-7.

56. Mineo MF, Franco-Asis GA, Del-Claro K. Repertório comportamental do escorpião amarelo Tityus serrulatus Lutz \& Mello1922 (Scorpiones, Buthidae) em cativeiro. Rev Bras Zoo. 2003 Jul 01,;5:23-31. 